\title{
Utilization of Cocoyam Production Technologies among Women Farmers in Abia State, Nigeria
}

Http://dx.doi.org/10.4314/jae.v20i1.2

\author{
Nwaobiala, C. U. \\ Department of Rural Sociology and Extension \\ Michael Okpara University of Agriculture Umudike, Abia State, Nigeria \\ Email: cunwaobiala@gmail.com \\ Phone: +2348061636932 \\ Uchechi, T. N \\ Department of Rural Sociology and Extension \\ Michael Okpara University of Agriculture Umudike, Abia State, Nigeria \\ Phone: +2348058924954
}

\section{Abstract}

The study analysed utilization of improved cocoyam production technologies among women in Abia State, Nigeria. A multistage random sampling technique was used to select sixty (60) women. Data for the study were collected using a structured questionnaire and analysed with descriptive statistics and inferential statistics (Logit regression model). The study revealed that the respondents had a mean age of 45.50 years, a mean farm size of 1.3 hectares, a bi-monthly contact with extension, while $73.33 \%$ sourced information on cocoyam production technologies from research institutes. The levels of utilization of cocoyam production technologies shows that the women utilized weed control $(\bar{x}=4.11)$, manure application $(\bar{x}=3.96)$, harvesting technologies $(\bar{x}=3.70)$, crop mixture $(\bar{x}=3.65)$ and time of planting $(\bar{x}=3.10)$, with a utilization index of $60.4 \%$. The result of Logit regression analysis showed that coefficient of education, farming experience, farm income, adaptability and accessibility of technology influenced women in utilizing cocoyam production technologies. Disease infestation, high cost of labour and infrequent visits by extension officers were identified as constraints to cocoyam production technologies utilization. The study recommends accessibility of technology through extension and development of hybrid cocoyam varieties that are adaptable to farmers' environment for increased cocoyam utilization.

Keywords: Utilization of cocoyam, production of cocoyam, cocoyam technologies, women in cocoyam 
Creative commons User License: CC BY-NC-ND

Abstracted by: EBSCOhost, Electronic Journals Service (EJS), Google Scholar, Directory of Open Access Journals (DOAJ),

Journal Seek, Scientific Commons,

Food and Agricultural Organization (FAO), and CABI
Journal of Agricultural Extension

Vol. 20 (1) June, 2016

ISSN(e): 24086851; ISSN(Print); 1119944X

http://journal.aesonnigeria.org

http://www.ajol.info/index.php/jae

Email: editorinchief@aesonnigeria.org

\section{Introduction}

Nigeria is the world's largest producer of cocoyam. The average production figure for Nigeria is 5.400 metric tonnes which accounts for about $37 \%$ of total world's output of cocoyam (FAO, 2012). Cocoyam is one of the major roots produced in large quantity in Nigeria. There are two main edible types of cocoyam in Nigeria; they are Colocasia esculentum and Xanthosoma saggittifolium. In Nigeria, cocoyam is regarded as a major crop especially in female headed households (Onwubuja and Ajani, 2012). Cocoyam is Nigerian's giant crop grown mainly for its corm and cormels. The crop has assumed nutritional and industrial significance in flour industries (Onwubuya and Ajani, 2012). It is nutritionally superior to yam and cassava in terms of its digestibility, contents of crude protein and essential minerals, such as $\mathrm{Ca}, \mathrm{Mg}$, and $P$ (Chukwu, 2012). All parts of the cocoyam (corm, cornel, leave and flower) are edible and it is used in the treatment of diabetes, prevention of cancer and as food for the aged people, individuals and children (Kundu et al., 2012).

Women farmers are the principal labour force on small holder farms and perform the largest share in land preparation, weeding, transporting, processing and marketing of agricultural products (Ugboaja, 2013; Odebode, 2012). This is found to be true in the case of cocoyam where women play an active role in cocoyam production, processing and marketing (Onyenobi et al., 2010). These women have contributed to over $60 \%$ of the labour force to food production and processing (Mgbada, 2000; Ogbonna and Nwaobiala, 2014). In Nigeria, cocoyam production is on the increase due to massive awareness created by the National Root Crops Research Institute (NRCRI, 2005). The institute developed cultivars of cocoyam that are resistance to disease and have high yield capacity, notably among these were; Nce011, Nce012, Nce003, Nce004, Nce005, Nce006, Nce007, Nce008, Nce009, Nce010, Nce011, Nce012, Nxs001, Nxs002, Nxs002, Nxs003, Nxs004 (FAO, 2012; Mbanaso et al., 2008). Upon these cultivars, resources allocation to cocoyam is significantly low when compared to other roots crops (Eke-Okoro, 2005). Rural women, need to be acquainted with new technologies, such they utilize them for increased cocoyam production.

In order to increase the yield of cocoyam cultivars, National Root Crops Research Institute, Umudike Abia State, Nigeria developed improved field production packages that involve early planting, application of appropriate levels of inorganic and organic soil amendment materials, mulching open field, suitable for inter-crops and time of operations and control of cocoyam root rot blight. Other agronomic practices disseminated to farmers include; using $25 \mathrm{~g}$ sett of cocoyam, time of planting (May-June), spacing $(60 \mathrm{~cm} \times 60 \mathrm{~cm}), 50 \mathrm{~cm} \times$ $50 \mathrm{~cm}$ for mixed cropping, use of mulching materials, NPK 20:10:10 fertilizers, planting depth $(10-50 \mathrm{~cm})$, pest control, weed control, crop mixture (arable crops), use of manure (side dressing application), harvesting (8-12months) (NRCRI, 2005). 
Creative commons User License: CC BY-NC-ND

Abstracted by: EBSCOhost, Electronic Journals Service (EJS), Google Scholar, Directory of Open Access Journals (DOAJ),

Journal Seek, Scientific Commons,

Food and Agricultural Organization (FAO), and CABI
Journal of Agricultural Extension

Vol. 20 (1) June, 2016

ISSN(e): 24086851; ISSN(Print); 1119944X

http://journal.aesonnigeria.org

http://www.ajol.info/index.php/jae

Email: editorinchief@aesonnigeria.org

Combination of factors like farmers socio-economic and socio-cultural characteristics were observed to exact influence on different ways of technology utilization (Unamma, 2004). Batx (1999) observed that risks involved in technologies were considered to determine farmer's opinion to use them or not. It is therefore, of opinion that those technologies which have risk characteristics when compared to their traditional alternative or practices will be utilized faster than technology with a low relative risk reduction (Nwaobiala, 2014). Information and innovation which are intended to improve agricultural production should be disseminated to farmers (male and female) and ultimately meet their need. However, variations exist on relevant production technologies needed by women farmers; lack of adequate access to extension service, low knowledge and skills in performing various farm operations has been an impediment to increase agricultural production (Ajala, et al., 2013). Women farmers has been by and large rejected by excising extension system, receiving about $5-7 \%$ of extension service due to their limited control over assets and decision making that are evident in agricultural institutions (RMRDC, 2004).

Production of cocoyam has not been given priority attention probably because of cocoyam's inability to earn foreign exchange and its unacceptability to high income groups for both consumption and other purposes (Edet and Nsikak, 2004). However, despite women roles in food crop production, there is dearth of empirical data on the state of utilization of cocoyam production technologies in the study area. As a result of these problems, this study provided answers to the following research questions:

i. What are the socio-economic characteristic of the women involved in cocoyam production in the study area?

ii. What are the source(s) of information by women cocoyam farmers in the study area?

iii. What are the levels of utilization of cocoyam production technologies by women farmers in the study area?

iv. What are the problems faced by women in using these production technologies?

The following specific objectives were stated. To:

i. describe the socio-economic characteristics of the respondents in the study area;

ii. identify source(s) of information on cocoyam production technologies by women farmers;

iii. assess the level of utilization of cocoyam production technologies by farmers in the study area; and

iv. identify the problems faced by women in using cocoyam production technologies in the study area. 
Creative commons User License: CC BY-NC-ND

Abstracted by: EBSCOhost, Electronic Journals Service (EJS), Google Scholar, Directory of Open Access Journals (DOAJ),

Journal Seek, Scientific Commons,

Food and Agricultural Organization (FAO), and CABI
Journal of Agricultural Extension

Vol. 20 (1) June, 2016

ISSN(e): 24086851; ISSN(Print); 1119944X

http://journal.aesonnigeria.org

http://www.ajol.info/index.php/jae

Email: editorinchief@aesonnigeria.org

\section{Hypothesis}

$\mathrm{H}_{0}$ : There is no relationship between farmers' characteristics and utilization of cocoyam production technologies among women farmers in Abia State, Nigeria

\section{Methodology}

This study was conducted in Abia State, Nigeria. Abia State lies between longitudes $7^{\circ} 23^{1}$ and $8^{\circ} 2^{1}$ East of the equator and latitudes $4^{\circ} 47^{1}$ and $6^{\circ} 12^{1}$ North of the Greenwich Meridian. The State is located East of Imo State and shares common boundaries with Anambra to the North, Enugu and Ebonyi states to the West and East respectively. On the East and South East, it is bounded by Cross River and Akwa Ibom States and by Rivers State on the South. Abia State is made up of 17 Local Government Areas (LGAs) and most of the people especially, the rural dwellers are engaged mainly in subsistence farming. They engage in arable crop production such as cassava, yam, cocoyam, rice, maize and sweet potatoes. Abia State has three agricultural zones namely Aba, Ohafia and Umuahia. The research was conducted in the two agricultural zones out of the three agricultural zones of Abia State namely Umuahia and Aba. A list of cocoyam women farmers that participated in cocoyam rebirth training organized by National Root Crops Research Institute Umudike which formed the sampling frame was collected from Abia State Agricultural Development Project (ADP). A multistage sampling technique was used in the selection respondents. First two (2) blocks each were randomly selected from the two agricultural zones (Umuahia zone - Ikwuano block, Umuahia North; Aba zone - Osiisoma block and Isiala Ngwa South) to give a total of 4 blocks. From the selected blocks three circles were randomly selected to give a total of 12 circles. Finally, five cassava farmers each were randomly selected from each of the selected circles to give a sample size of 60 cocoyam farmers. A structured questionnaire was used to elicit information from the farmers. Objectives i, ii, iii and iv were achieved with descriptive statistics such as frequency counts, percentages and mean scores, while the hypothesis tested was achieved with Logit regression analysis. The levels of utilization of cocoyam production technologies by women farmers was achieved using a 5-point Likert type scale of; always $=5$, often $=4$, sometimes $=3$, rarely $=2$, and never $=1$. Based on the mid score decision rule, any mean score of 3.0 and above imply that they utilized the technology, while respondents with mean score of less than 3.0 do not utilize the technologies.

The utilization indices of the respondents were calculated According to Nwalieji et al., (2014):

a) Computation of the total mean utilization score per technology. This was computed by dividing the total utilization score by the number of respondents involved.

b) Computation of the grand mean adoption score. This was calculated by adding all the mean utilization scores and dividing by the number of innovations considered. 
Creative commons User License: CC BY-NC-ND

Abstracted by: EBSCOhost, Electronic Journals Service (EJS), Google Scholar, Directory of Open Access Journals (DOAJ),

Journal Seek, Scientific Commons,

Food and Agricultural Organization (FAO), and $C A B I$
Journal of Agricultural Extension Vol. 20 (1) June, 2016

ISSN(e): 24086851; ISSN(Print); $1119944 X$ http://journal.aesonnigeria.org http://www.ajol.info/index.php/jae Email: editorinchief@aesonnigeria.org

c) Computation of the utilization index. This was carried out by dividing the total mean adoption score by 5 - point Likert type scale.

\section{Model Specification}

\section{The Logit Regression Model}

The factors that influence the utilization of cocoyam production technologies by women farmers were determined using Logit regression analysis.

The model in this study is based on the assumption that utilization of cocoyam technologies by farmers is likely to be impacted by many factors. These factors are related to technology attributes such as; education, farming experience, farm income, farm size, cost of input, quantity of input, quality of input, extension contact, availability of input and distance.

The model parameters are estimated by maximizing this log likelihood function with respect to parameters that is, the parameters reported in the paper are those of which the likelihood function is at maximum.

The estimate Logiit model has the following specifications;

$y=\beta_{0}+\beta_{1}+\beta_{2}+\beta_{3}+\beta_{4}+\beta_{5}+\beta_{6}+\beta_{7}+\beta_{8}+\beta_{9}+\beta_{10+} e_{1}$

Where,

$y=$ technology utilization (utilized $=1$, not utilized $=0$ )

$\beta_{o}=$ A vector of estimated parameter

$\beta_{1}=$ education level (years)

$\beta_{2}$ = farming Experience (years)

$\beta_{3}=$ farm income $(\AA)$

$\beta_{4}=$ farm size (hectares)

$\beta_{5}=$ cost of input $(A)$

$\beta_{6}=$ quantity of input $(\mathrm{kg})$

$\beta_{7}=$ quality of input (yes $=1$, otherwise $=0$ )

$\beta_{8}=$ extension contact (number visit by extension agent)

$\beta 9=$ availability of input (yes $=1$, otherwise $=0$ )

$\beta_{10}=$ distance $(\mathrm{km})$

$\beta_{1}-\beta_{10}=$ parameters to be studied

$e_{1}=$ error term

\section{Distribution of Socio-economic Characteristics of Respondents}

The socio-economic characteristics of respondents are shown in Table 1. The result reveals that $51.67 \%$ of the women were married, $30.00 \%$ of them widowed, $11.67 \%$ were single, while $6.67 \%$ were divorced. This implies that 
Creative commons User License: CC BY-NC-ND

Abstracted by: EBSCOhost, Electronic Journals Service (EJS), Google Scholar, Directory of Open Access Journals (DOAJ),

Journal Seek, Scientific Commons,

Food and Agricultural Organization (FAO), and $C A B I$
Journal of Agricultural Extension

Vol. 20 (1) June, 2016

ISSN(e): 24086851; ISSN(Print); 1119944X

http://journal.aesonnigeria.org

http://www.ajol.info/index.php/jae

Email: editorinchief@aesonnigeria.org

married people dominate in agricultural activities in Nigeria (Onwubuya et al., 2009). The mean age of the respondents was 45.4 years. The implication of this finding shows that the women were strong being in their productive age (Olaniyi and Adewale, 2014). The mean household size of the women was 9.5 persons. The result implies that large household size may be an advantage to farmers in terms of farm labour supply. Bauchi et al., (2008), asserted that household size is the most important input for unpaid labour. This result further indicates that $35.0 \%$ of the women acquired secondary education. Educated farmers are expected to be more receptive to improved farming techniques, while farmers with low level of education or without education would be less receptive to improved farming techniques (Yahaya, 2002). The table also reveals that the respondents had a mean farming experience of 20.5 years. With more experience, a farmer can become less averse to the risk implied by adopting a new technology (Nwaobiala, 2014). The result indicates that the mean farm size of the respondents was 1.3 hectares. The result indicates that cocoyam production in the study is dominated by smallholder scale producers. Farm size affects adoption costs, risk perceptions, human capital, credit constraint, labour requirements, tenure arrangements and more. With small farms, it has been argued that large fixed costs become a constraint to technology adoption (Abana and Singh, 1993) especially if the technology is costly (Okoye et al., 2009). The mean annual farm income of the women was $\$ 20,900.00$, while $66.67 \%$ of the respondents had bi-monthly contact in the study area. It is hypothesized that contact with extension workers and adequate information on production techniques will increase farmer's likelihood of adoption of improved agricultural practices (Salau et al., 2014). 
Creative commons User License: CC BY-NC-ND

Abstracted by: EBSCOhost, Electronic Journals Service (EJS), Google Scholar, Directory of Open Access Journals (DOAJ),

Journal Seek, Scientific Commons,

Food and Agricultural Organization (FAO), and CABI
Journal of Agricultural Extension Vol. 20 (1) June, 2016

ISSN(e): 24086851; ISSN(Print); $1119944 X$ http://journal.aesonnigeria.org http://www.ajol.info/index.php/jae Email: editorinchief@aesonnigeria.org

Table 1: Distribution of selected socio-economic characteristics of cocoyam women farmers in Abia State, Nigeria

\begin{tabular}{|c|c|c|}
\hline Variables & Percentage $(n=60)$ & Mean \\
\hline \multicolumn{3}{|l|}{ Marital Status } \\
\hline Married & 51.67 & \\
\hline Single & 11.67 & \\
\hline Divorced & 6.67 & \\
\hline Widowed & 30.00 & \\
\hline \multicolumn{3}{|l|}{ Age (years) } \\
\hline $20-30$ & 22.22 & \\
\hline $31-40$ & 34.44 & \\
\hline $41-50$ & 18.89 & \\
\hline $51-60$ & 17.78 & 45.4 years \\
\hline $61-70$ & 3.33 & \\
\hline \multicolumn{3}{|l|}{ Household Size (numbers) } \\
\hline $1-4$ & 23.33 & \\
\hline $5-7$ & 16.67 & \\
\hline $8-11$ & 50.00 & 9.5 persons \\
\hline $12-15$ & 10.00 & \\
\hline \multicolumn{3}{|l|}{ Education } \\
\hline No Formal Education & 13.33 & \\
\hline Primary School Education & 31.67 & \\
\hline Secondary School Education & 35.00 & \\
\hline Tertiary School Education & 20.00 & \\
\hline \multicolumn{3}{|l|}{ Farming Experience ()years) } \\
\hline $1-10$ & 13.33 & \\
\hline $11-20$ & 21.67 & \\
\hline $21-30$ & 23.33 & 20.5 years \\
\hline $31-40$ & 24.44 & \\
\hline \multicolumn{3}{|l|}{ Farm Size (hectares) } \\
\hline $0.1-0.5$ & 38.33 & \\
\hline $0.6-1.0$ & 11.67 & \\
\hline $1.1-1.5$ & 25.00 & 1.3 hectares \\
\hline $1.6-2.0$ & 16.67 & \\
\hline $2.1-2.5$ & 8.33 & \\
\hline \multicolumn{3}{|l|}{ Annual Farm income (N) } \\
\hline $5,000-10,000$ & 15.00 & \\
\hline $11,000-15,000$ & 11.67 & \\
\hline $16,000-20,000$ & 1.67 & N20.900.00 \\
\hline $21,000-30,000$ & 50.00 & \\
\hline $31,000-50,000$ & 21.67 & \\
\hline \multicolumn{3}{|l|}{ Extension Contact } \\
\hline None & 13.33 & \\
\hline Weekly & 1.67 & \\
\hline Forth nightly & 8.33 & \\
\hline Monthly & 10.00 & \\
\hline Bi- monthly & 6.67 & \\
\hline
\end{tabular}

Source: Field Survey Data, 2014

Sources of Information on Cocoyam Production Technologies by Women Farmers

Table 2 shows the frequency distribution of respondents according to sources of information in cocoyam production technologies by farmers in the study area. The results show that the most important source of agricultural 
Creative commons User License: CC BY-NC-ND

Abstracted by: EBSCOhost, Electronic Journals Service (EJS), Google Scholar, Directory of Open Access Journals (DOAJ),

Journal Seek, Scientific Commons,

Food and Agricultural Organization (FAO), and CABI
Journal of Agricultural Extension

Vol. 20 (1) June, 2016

ISSN(e): 24086851; ISSN(Print); 1119944X

http://journal.aesonnigeria.org

http://www.ajol.info/index.php/jae

Email: editorinchief@aesonnigeria.org

information in the area was Research Institutes (73.33\%), followed by extension agent visits (46.6\%) and ADP/Ministry of Agriculture (26.67\%). Agricultural information needs are as important as other resources for agricultural production. Aphunu and Agwu (2013) affirmed that farmers whether small, medium or large scale, need information on production recommended technologies for farm management, acquisition, allocation and utilization of farm resources.

Table 2: Frequency distribution of respondents according to sources of information on cocoyam production technologies in the study area

\begin{tabular}{lc}
\hline Sources of information & Percentage \\
\hline Research Institutes & 73.33 \\
ADP/Ministry of Agriculture & 26.67 \\
Attending field-days & 6.67 \\
Extension Agent Visits & 46.67 \\
Radio programme & 6.67 \\
Television programme & 16.67 \\
Fellow cocoyam farmers & 6.67 \\
Extension training programmes & 3.33 \\
Personal observation & 20.00 \\
\hline
\end{tabular}

Source: Field Survey, 2014.

Multiple responses recorded

\section{Levels of Utilization of Cocoyam Production Technologies by Women Farmers}

The results in Table 3 show the level of utilization of cocoyam production technologies by women farmers in the study area. The result show that the production technologies utilized by the women include; weed control ( $\bar{x}=$ $4.11)$, use of manure $\left(\bar{x}_{=} 3.96\right)$, harvesting $\left(\bar{x}_{3.70}\right)$, crop mixture $\left(\bar{x}_{=}=3.65\right)$ and time of planting, $(\bar{x}=3.10)$. The implication of the result shows that the total mean of cocoyam production technologies by women was 3.02 with a utilization index of $60.4 \%$, indicating they adopted these technologies since the mean score is above 3.0. The result is in conformity with Okoye et al., (2009) where they found that cocoyam women farmers in Enugu North Local Government Area of Enugu State adopted most of these technologies. 
Table 3: Levels of utilization of cocoyam production technologies by women farmers in the study area

\begin{tabular}{lc}
\hline Production Technologies & Mean \\
\hline 25g sett of cocoyam & 2.38 \\
Time of planting (May -June) & 3.10 \\
Spacing $(100 \mathrm{~cm} \times 50 \mathrm{~cm})$ & 2.62 \\
Fertilizer (NPK $20: 10: 10)$ & 2.65 \\
Planting depth $(10 \mathrm{~cm})$ & 2.35 \\
Pest control & 1.65 \\
Weed control & 4.11 \\
Crop mixture (Tree Cropping) & 3.65 \\
Use of manure & 3.96 \\
Harvesting & 3.70 \\
Grand mean & $\mathbf{3 0 . 1 7}$ \\
Total mean & $\mathbf{3 . 0 2}$ \\
Utilization index & $\mathbf{0 . 6 0 4}$ \\
\hline
\end{tabular}

Source: Field Survey, 2014

Decision Rule: 3.0 and above = utilization, less than $3.0=$ non utilization

\section{Relationship between Farmers' Characteristics and Utilization of Cocoyam production Technologies among Women Farmers in Abia State, Nigeria}

Table 4 shows the Logit regression estimates of the determinants of utilization of cocoyam production technologies in Abia State. The $\mathrm{Chi}^{2}\left(\varkappa^{2}\right)$ value of 34.97 was highly significant at $1 \%$ level of probability indicating a Logit regression of best fit. The Pseudo $\mathrm{R}^{2}$ value of 0.7076 indicates $70.76 \%$ variability in cocoyam technology utilization was explained by the independent variables. The coefficient for education was positive and significant at $10 \%$ level of probability. This implies that any increase in education will lead to increase in probability and intensity of technology utilization among the farmers in the study area. Education is thought to create a favourable mental attitude for the acceptance of new practices especially on informationintensive and management-intensive practices (Caswell et al., 2001). The coefficient of farming experience was also positive and significant at $1 \%$ level of probability. This implies that an increase in farming experience will lead to increase in probability and intensity of technology utilization in the study area. Increased utilization is thought to stem from accumulated knowledge and experience of farming systems obtained from years of observation and experimenting with various technologies (Bonabana-Wabbi, 2002). The coefficient for farm income was positive and significant at 5 level of probability. This implies that any increase in income will lead to increase in technology utilization among the farmers in the study area. Kehinde (2013) noted that the decision to adopt is often an investment decision. Technologies that are capital-intensive are only affordable by wealthier farmers (EL Oster and Morchert, 1999) hence the adoption of such technologies is limited to larger 
Creative commons User License: CC BY-NC-ND

Abstracted by: EBSCOhost, Electronic Journals Service (EJS), Google Scholar, Directory of Open Access Journals (DOAJ),

Journal Seek, Scientific Commons,

Food and Agricultural Organization (FAO), and CABI
Journal of Agricultural Extension Vol. 20 (1) June, 2016

ISSN(e): 24086851; ISSN(Print); $1119944 X$ http://journal.aesonnigeria.org http://www.ajol.info/index.php/jae Email: editorinchief@aesonnigeria.org

farmers who have wealth (Khanna, 2001). The coefficient for adaptability and accessibility of technologies were all positive and highly significant at $1 \%$ level of probability. This implies that any increase in these variables will increase the probability and intensity of technology utilization in the study area. Acquisition of information about a new technology demystifies it and makes it more available to farmers (Oladeja et al., 2006).

Table 4: Determinants of technology utilization among cocoyam women farmers in the Abia State, Nigeria

\begin{tabular}{|c|c|c|c|}
\hline Variables & Coefficient & Standard error & t-value \\
\hline Constant & 15.2085 & 3.9807 & $3.81^{* * *}$ \\
\hline Age $\left(X_{1}\right)$ & 0.0179 & 0.0597 & 0.30 \\
\hline Marital status $\left(\mathrm{X}_{2}\right)$ & -0.2347 & 0.8022 & -0.29 \\
\hline Education $\left(X_{3}\right)$ & 1.3805 & 0.7150 & $1.93^{*}$ \\
\hline Farming experience $\left(X_{4}\right)$ & 0.0470 & 0.0130 & $3.61^{* * *}$ \\
\hline Household size $\left(X_{5}\right)$ & -0.2474 & 0.2124 & -1.16 \\
\hline Farm Income $\left(X_{6}\right)$ & 0.00047 & 0.00017 & $2.76^{\star \star}$ \\
\hline Extension Contact $\left(\mathrm{X}_{7}\right)$ & -0.15447 & 0.3705 & 0.42 \\
\hline Adaptability $\left(\mathrm{X}_{8}\right)$ & 3.2080 & 0.7695 & $4.12^{\star \star \star}$ \\
\hline Accessibility $\left(X_{9}\right)$ & 0.7178 & 0.7604 & $4.22^{\star \star \star}$ \\
\hline Farm size $\left(X_{10}\right)$ & -0.2981 & 0.2590 & -1.15 \\
\hline Chi $^{2}\left(x^{2}\right)$ & $34.97^{\star \star \star}$ & & \\
\hline Pseudo $\mathrm{R}^{2}$ & 0.7076 & & \\
\hline Log likelihood & -144.9756 & & \\
\hline
\end{tabular}

$P \leq 10,{ }^{* *} P \leq 0.5$ and ${ }^{* *} P P \leq 0.1$

Source: Field survey, 2014.

\section{Constraints Militating Against the Utilization of Cocoyam Production Technologies}

Table 5 show frequency distribution of respondents militating against the utilization of cocoyam production technologies by women in the study area. The most important constraint was disease infestation $(91.67 \%)$ followed by high cost of labour (85.00\%), infrequent visit by extension officers $(70.00 \%)$ and complexity of technology (33.33\%).

Table 5: Distribution of respondents according to constraints militating against utilization of cocoyam production technologies in the study area Constraints

Complexity of technologies Percentage

High cost of planting materials

33.33

Accessibility to information

18.33

Disease infestation

15.00

Unavailability of land

91.67

Socio-cultural factors

High cost of labour

15.00

Infrequent visit by extension officers

85.00

Multiple responses

Source: Field Survey, 2014. 


\section{Conclusion and Recommendations}

The study showed that most of the women farmers sourced cocoyam production technologies from research institutes and extension agents and utilized selected cocoyam production technologies such as weed control, use of manure, harvesting, crop mixture and time of planting. The study also proved that socio-economic characteristics and technology attributes influenced women utilization of cocoyam production technologies in the study area.

There is need to encourage experienced farmers to increase the utilization of improved cocoyam technologies for increased income and productivity. This will be achieved by organizing seminars and workshops for the women. There is need to increase the accessibility of the technologies by creating awareness through the extension services.

Researchers should develop hybrid cocoyam varieties that are adaptable to farmers' environment. This will help increase the output of cocoyam

\section{References}

Aphunu, A. and Agwu, A. E. (2013). Information and training needs of clustered fish farmers in Delta State, Nigeria. Implication for transformation of the fishery sub - sector. Conference proceedings of the $18^{\text {th }}$ annual conference of agricultural extension society of Nigeria (AESON) Pp $7-16$.

Ajala, A. O., Ogunjimi, S.I. and Farinde, A.J. (2013). Assessment of extension service delivery on improved cassava technologies among cassava farmers in Osun State, Nigeria. International Journal of Applied Agricultural and Apicultural Research 9(1\&2): 71- 78.

Bauchi, B.M, Madukwe, M.C, Dauda, S. and Onwubiya, I.A. (2008). Emerging policy issues in the special crop production programme in Benue State, Journal of Agricultural Extension 12 (1): 96 - 104.

Batx, F.J. (1999). Improving priority setting for livestock research by using technologies characteristics for adoption assessments Ph.D Dissertation, Berlin, Germany.

Bonabana-Wabbi, J. (2002). Assessing factors affecting adoption of agricultural technologies: The case of integrated pest management (IMP) in Kumi District, eastern Uganda. MSc thesis in Agricultural and Applied Economics the Virginia Polytechnic Institute and State University

Caswell, M., Fuflie, K., Ingram, C., Jans, S. and Kascak, C. (2001). Adoption of agricultural production practices: Lessons learned from the US department of agricultural area studies project. Washington DC. US department of Agricultural resource economics division, economic research service, agricultural economics report, No. 792. 
Chukwu, G.O., Nwosu K.I., Mbanaso E.N.A., Onwubiko O., Okoye B.C. (2012). Cocoyam re-birth initiative, Annual Report, national root crops research institute (NRCRI) Umudike, Pp 119-121.

Edet, J.U., and Nsikak, A.A. (2004). Cocoyam farms in Akaw Ibom State, Nigeria. A production frontier approach. Longman group limited London.

Eke-Okoro, O.E. (2005): Nigerian cocoyam and ginger cultivars. Root and tuber expansion programme (RTEP) Pp 1-2.

Food Agricultural Organization (FAO) (2012). Root and tuber crops in developing countries, challenges and opportunities Pp 11-13.

Kehinde, E. A. (2010). A Review of Factors Affecting use of agricultural extension services by small scale farmers in food production in Kwara State, Nigeria. conference proceedings of the $18^{\text {th }}$ annual conference of agricultural extension society of Nigeria (AESON) Pp 154 -160 .

Khanna, M. (2001). Sequential adoption of site Specific technology and its implications for nitrogen productivity: A double selectivity model. American Journal of Agricultural Economics 83(1): 35-51.

Kundu, N., Campbell, P. and Hampton, A. (2012): Anti - metastatic activity isolated from Colocasia esculenta (Taro). Anti-cancer drugs, Pp 200-211.

Mbanaso, E.N.A, Onwubiko, O and Okoye, B.C (2008). Briefs on cocoyam production. Cocoyam programme national root crops research institute, Umudike, Abia State, Nigeria.

Mgbada, J.U. (2000). Production of stable crops by rural women in Enugu and Ebonyi States. In T. Olowu (Ed). Extension in poverty alleviation in Nigeria. Proceedings of the $6^{\text {th }}$ annual national conference of agricultural society of Nigeria (ASN). Pp. $10-12$.

National Root Crops Research Institute (NRCRI) (2005). Cocoyam improvement programme. Annual report national root crops research institute, Umudike. Pp 21.

Nwalieji, H. U., Madukwe, M. C., Agwu, A. E. and Umerah, M. I. (2014). Adoption of rice technologies introduced by the United States agency for international development in Anambra and Ebonyi States, Nigeria. Journal of Agricultural Extension, 8(1): 158 - 169. 
Nwaobiala, C. U, Ogbonna, M. O and Egbutah, E. U. (2014). Assessing levels of participation among farmers' in IFAD/FGN/NDDC/communitybased natural resource management programme technologies in Abia and Cross River State, Nigeria. Discourse Journal of Agriculture and Food Science 2(5):85-90. www.resjournals.org/JAFS.

Nwaobiala, C. U. (2014). Adoption of fish production technologies among homestead catfish farmers in Ebonyi State, South-east, Nigeria. Journal of Applied Agricultural Research 6(2): 75-84.

Odebode, S.O. (2012). Gender issues in agricultural extension and rural development in Nigeria. In: Adisa, S.S (eds) rural development contemporary issues and practices; In tech; http://vwvv.intechopen.com/books/rural-development-coemporaryissues-add-practices.

Ogbonna, M. O.and Nwaobiala, C. U. (2014). Effect of fadama III development project on rural farm women production in Gombe State, Nigeria. Nigerian Journal of Agriculture, Food and Environment (NJAFE) 10(1):13-18. www.njafe.org.

Oladeja, M. A., Adisa, B. O. and Ahmed-Akinola, A. A. (2006). "Effectiveness of communication method used in information delivery to cocoa farmers in Oluyole local government area, Oyo State, Nigeria". The Ogun Journal of Agricultural Science, 1(4):78 - 88.

Olaniyi, O. A. and Adewale, J. O. (2013). Women farmer's perception utilization of market information on cassava in Osun State, Nigeria. Journal of Agricultural Extension 17 (2): $23-32$.

Onwubuya, E.A. and Ajani, E.N. (2012). Strategies for improving production and processing of cocoyam among women in Anambra State, Nigeria. Universal Journal of Education and General Studies 1 (16) $169-173$.

Onyenobi, V.O., Chukwu, G.O., Asumugha, G.N., Okoye, B.C., Ewuziem, J.E., Ogbonna, M.C. and Akinkpelu, A.O. (2010). Marking of edible cocoyam, xanthosoma species (tannia) in Abia State Nigeria. National root crops research institute Umudike, Abia State annual report no. 10 vol. 15.

Raw Materials Research Development Council (RMRDC) (2004). Report on summary of agro-raw materials in Nigeria. Federal ministry of science and technology, Abuja. 
Creative commons User License: CC BY-NC-ND

Abstracted by: EBSCOhost, Electronic Journals Service (EJS), Google Scholar, Directory of Open Access Journals (DOAJ), Journal Seek, Scientific Commons,

Food and Agricultural Organization (FAO), and CABI
Journal of Agricultural Extension

Vol. 20 (1) June, 2016

ISSN(e): 24086851; ISSN(Print); $1119944 X$ http://journal.aesonnigeria.org http://www.ajol.info/index.php/jae

Email: editorinchief@aesonnigeria.org

Salau, E. S, Saingbe, N. D. and Garba, M. N. (2013). Agricultural Information Needs of Small Holder Farmers in Central Agricultural Zone of Nasarawa State, Nigeria. Nigerian Journal of Agricultural Extension $7(2): 127-135$.

Ugboaja, M. (2013). Enhancing income thought cocoyam production, processing and consumption patterns in Dunukofia local government of Anambra State Nigeria; Greener Journal of Social Science 3(6); 336-339.

Unamma, R.P.A. (2004). Agricultural technology generation and transfer strategies for food security. Proceeding of the $6^{\text {th }}$ annual zonal research and extension farmers input linkage systems (REFILS). Workshop south and south/south zone of Nigeria 12-13 November.

Yahaya, M. K. (2002). Gender and communication variables in agricultural information in three agro-ecological zones of Nigeria. Cooperate graphics Ltd, Ibadan Pp $200-203$. 